\title{
Virtual Training Prepared for the Former Afghanistan Ministry of Energy and Water-Streamgaging, Fluvial Sediment Sampling, Bathymetry, and Streamflow and Sediment Modeling
}

\section{Introduction}

The U.S. Geological Survey (USGS) created a virtual training series for the Afghanistan Ministry of Energy and Water (MEW), now known as the National Water Affairs Regulation Authority (NWARA), to provide critical hydrological training as an alternative to an in-person training. The USGS was scheduled to provide in-person surface-water training for NWARA during 2020; however, travel was halted because of the Coronavirus disease 2019 (COVID-19) pandemic. The virtual training consisted of prerecorded and live presentations that were scheduled during 4 weeks in August 2021. However, the training was halted after the second week due to the collapse of the Afghan Government. Fortunately, the prerecorded presentations and training materials were delivered before the trainings were halted, so they can be viewed or shared by the participants in the future. A benefit to having produced prerecorded trainings is that USGS can leverage or adapt the trainings for nongovernmental organizations (NGOs) involved in humanitarian water relief efforts in Afghanistan or can be used for other international training efforts.

\section{Background}

Since 2004, the USGS has aided efforts to rebuild Afghanistan's capacity to monitor water resources by collaborating with scientists from different Afghan Government agencies, including the MEW, NWARA, and the Afghanistan Ministry of Agriculture, Irrigation, and Livestock (MAIL). The USGS has worked to compile and (or) recover Afghanistan's hydrologic data and has provided trainings on water-resource data collection in the past (Mack and others, 2014). These collaborations have assisted Afghan scientists in developing the data collection networks necessary for improved understanding and management of water resources that may affect current and future water supplies and conditions.

\section{Goals}

The goal of the virtual trainings was to efficiently provide surface-water capacity training to NWARA. Because the trainings were prerecorded and delivered prior to training events, the recordings could be viewed during the trainee's schedule or at locations with limited internet access. This approach made the trainings more accessible with the large time zone difference between the United States and Afghanistan. Alternatively, any training that is not recorded can be difficult for the participants to recall key information after the training has ended if detailed notes were not transcribed. The prerecorded trainings provided the participants with the opportunity to translate, pause, or view multiple times during the trainings.

\section{Training Format}

The prerecorded and live trainings were scheduled to be presented to the Afghanistan Ministry of Energy and Water during a 4-week period. The learning objective was to better understand how to collect useful and meaningful surface-water data as a basis for understanding hydrologic processes and management of water resources. Each week consisted of three components:

- 1-hour live introduction to the weekly topic

- subject material (sent weekly)

o prerecorded presentations

o videos

o exercises

- 2-hour live summary of the weekly topic with a questionand-answer session at the end of the week

Each training topic was developed to be completed in a week; however, trainings were self-guided, and participants could complete the trainings at their own pace. The following four sections highlight the training topics and objectives during the 4-week period.

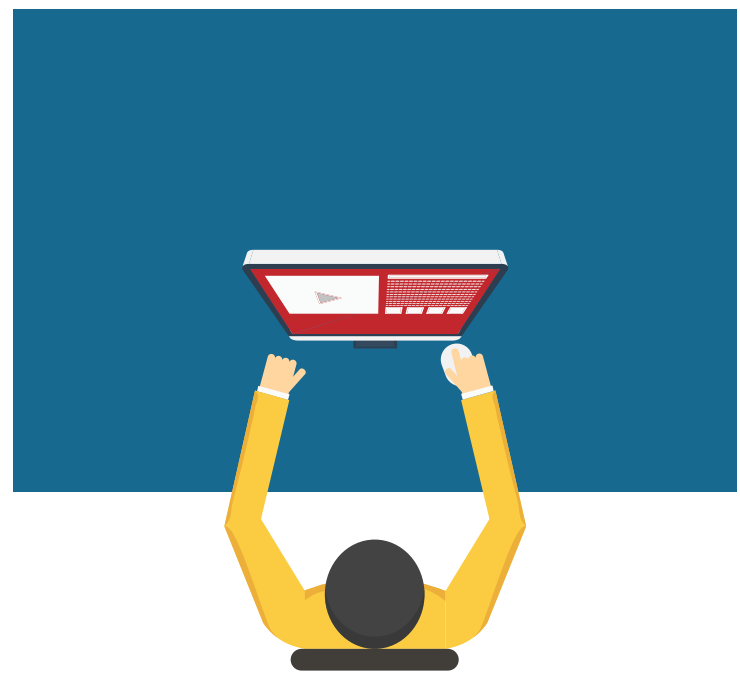

Training materials were delivered electronically to participants. 


\section{Week 1 Topic-Streamflow Gaging}

- Learn about the importance of stage (water elevation) data. This is the base for most derived hydrologic variables (for example, streamflow) and hydrologic forecasting (models and flood forecasting)

- Learn typical field methods and streamgaging operations

- Learn how to analyze recorded and derived data

\section{Week 2 Topic-Fluvial Sediment Sampling}

- Learn why it is important to collect accurate sediment data

- Learn how to collect different types of sediment data

- Learn how to set up a study that incorporates sedimentsampling data

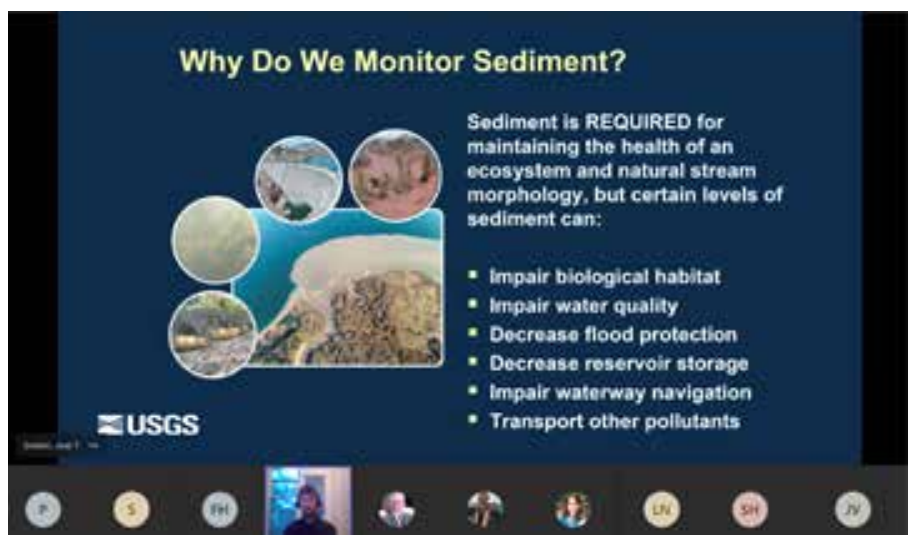

Example of live introduction to the weekly topic.

\section{Week 3 Topic-Bathymetry}

- Learn about bathymetry and its uses

- Learn how to accurately collect, process, and quality check bathymetry data

- Review examples of useful products from bathymetry studies

\section{Week 4 Topic_-Streamflow and Sediment Modeling}

- Learn how to analyze collected sediment data

- Learn about different types of surface-water models

- Learn how to operate a surface-water model with practical examples

\section{Advantages}

The virtual format developed by USGS provided cost savings because trainings were delivered electronically and required no travel costs. In-person trainings are useful, but this format could be used in the future to communicate introductory materials, so more targeted trainings or collaborative work can happen in person. Additionally, depending on the audience, more general trainings can be used for other purposes and not just a single use. The format provides the opportunity to repurpose the trainings for other uses, or the current trainings can be shared with others in the local, national, and (or) international communities.

\section{Summary}

The U.S. Geological Survey provided quality, surface-water capacity training to the Afghanistan National Water Affairs Regulation Authority (NWARA) during 2021 when travel restrictions prevented in-person trainings from being held. The virtual format consisted of prerecorded presentations and live trainings that were scheduled to be delivered during a 4-week period in August 2021. The live training was halted after the second week because of the collapse of the Afghan Government; however, the prerecorded presentations were provided before the trainings ended. The trainings consisted of the following topics: streamflow gaging, fluvial sediment sampling, bathymetry, and streamflow and sediment modeling. Each topic included specific learning objectives to better understand how to collect useful and meaningful surface-water data as a basis for understanding hydrologic processes and management of water resources. These prerecorded trainings can be leveraged or adapted for nongovernmental organizations (NGOs) involved in humanitarian water relief efforts in Afghanistan or can be used for other international training efforts.

\section{Acknowledgments}

Many individuals have contributed to the successful collaboration between the U.S. Geological Survey (USGS) and the former Afghanistan Ministry of Energy and Water (MEW), now known as the National Water Affairs Regulation Authority (NWARA). Special recognition goes to Kevin Vining, USGS retired, for initial planning and coordination of the surface-water training; and Molly Wood, USGS, who assisted with the fluvial sediment-sampling topic. Erik Smith and Jamie Velkoverh, USGS, are acknowledged for their reviews of the report.

\section{References Cited}

Mack, T.J., Chornack, M.P., Vining, K.C., Amer, S.A., Zaheer, M.F., and Medlin, J.H., 2014, Water resources activities of the U.S. Geological Survey in Afghanistan from 2004 through 2014: U.S. Geological Survey Fact Sheet 2014-3068, 6 p., accessed November 2021 at https://doi.org/10.3133/fs20143068.

By Joel T. Groten, Joshua F. Valder, Brenda K. Densmore, Logan W. Neal, Justin Krahulik, and Thomas J. Mack

For more information about this publication, contact:

Director, USGS Office of International Programs

411 National Center

12201 Sunrise Valley Drive

Reston, VA 20192

DirectorOIP@usgs.gov

For additional information, visit:

https://www.usgs.gov/international-programs

Publishing support provided by

Rolla and Lafayette Publishing Service Centers

ISSN 2327-6932 (online) https://doi.org/10.3133/fs20223014 